\title{
Visegrad Countries and Regions: Innovation Performance and Efficiency
}

\author{
DOI: 10.12776/QIP.V19I2.593
}

\author{
Oto Hudec, Martina Prochádzková
}

Received 7 August 2015, Accepted 12 October 2015, Published 31 December, 2015

\begin{abstract}
Purpose: The aim of the article is to study the differences between efficiency of their research and innovation systems, innovation performance and efficiency of the Visegrad countries (Czech Republic, Hungary, Poland and Slovakia) as well as their regions.
\end{abstract}

Methodology/Approach: Visegrad countries are to be compared according to national innovative capacity framework based on the composite index methodology The regional innovation efficiency is examined by considering R\&D expenditures as inputs and patents as outputs. The efficiency of the regional research and innovation systems is based on the concept of knowledge production function (Cobb - Douglas type).

Findings: Visegrad countries do not belong among the best performers in innovation and competitiveness in the European Union. The findings show a substantial difference if replacing commonly evaluated innovation performance by the efficiency. Except the capital regions, there are several Polish and Czech regions which belong to the most efficient in innovation in the Visegrad regional comparison: Lodzkie, Lesser Poland, Central Moravia and South-East Moravia.

Research Limitation/implication: The research shows the limitation of the innovation performance as published by the European Commission in a form of Regional Innovation Monitor.

Originality/Value of paper: The approach of relative efficiency evaluation shows a rather different picture in comparison to previous static models and comparisons.

Category: Research paper

Keywords: efficiency; innovation system; knowledge production function; innovation performance 


\section{INDICATORS AND MEASUREMENT OF INNOVATION PERFORMANCE}

The innovative capacity of a country/region can be considered as its ability to produce and commercialize innovations to drive long-term economic growth and wealth creation. From this perspective, the capacity depends mainly on the innovation infrastructure, the innovation environment and the relationships between those two determinants. The drivers of the innovation processes at the national level are highlighted mainly in three integrated viewpoints: ideas-driven growth theory, microeconomics-based models of national competitive advantage and industrial clusters, and the concept of national innovation systems (Furman, Porter and Stern, 2002). Each of three approaches tries to indicate and measure country-specific factors determining the flow of innovation towards a new-tothe-world innovation production, or to define the real and potential capabilities of a spatial system to convert knowledge into innovation (Lundvall and Johnson, 1994; Furman, Porter and Stern, 2002; Schiuma and Lerro, 2008).

The microeconomics-based models of national competitive advantage and industrial clusters study factors of microeconomic environment related to the technological innovation and economic growth (Furman, Porter and Stern, 2002). Porter (1990) recognized four key economic drivers:

1) Availability of high-quality and specialized innovation inputs (availability of the R\&D personnel),

2) Local competitive contest focusing on the intense and rewards successful innovators (IP protection, cluster-specific incentives),

3) The nature of domestic demand for cluster producers and services (quality-sensitive local customers),

4) Availability, density and interconnectedness of vertically and horizontally related industries (making positive externalities).

The growth potential of each country depends principally on the national educational system, industrial relations, technical and scientific institutions, cultural traditions, government interventions and other factors and institutions (Freeman, 1995). National innovation system (NIS) is focused on the structure description of organizations and activities, which contribute to the innovative behaviour of each country with the main aim to identify key players and the role of government in the observed system. NIS can be considered as one from a lot of factors that determine the flow of innovations in a country and in this way NIS contributes to the national innovation capacity.

The concept of national innovation systems emphasizes the importance of the organization and partners of activity that contribute to production and commercialization of innovations in a country, pointing out the crucial role of government policy and particular institutions. According to the national 
innovation systems approach, countries differ through the nature of their university systems, the extent of intellectual policy protection, the historical evolution of the industrial R\&D organization and the division of labour between the actors of the Triple Helix segments - universities, private industries and government (Freeman, 1995; Lundvall and Johnson, 1994). All three segments explain production and diffusion of innovation through the political and economic factors and the country innovative capacity is explained by technological superiority of the economy, labour force, investments and policy choices (government and private sector). The differences among countries are on the side of economic geography but also on the side of innovation policy (level of public support, IP protection). Furman, Porter and Stern (2002) classify determinants of the national innovative capacity into three groups: common innovation infrastructure, the cluster-specific innovation environment, the quality of linkages.

Patents are the most common proxy variable for the measurement of the innovative output, but the "realistic" rate of technological innovation is unobservable. The next table consists of the sub-determinants which are considered on the input side of the innovative processes categorized into three mentioned groups and a fourth group is added covering related:

Table 1 - Determinants of National Innovative Capacity

\begin{tabular}{|l|l|}
\hline Group & Variable \\
\hline A: Quality of the common & GDP per capita \\
innovation infrastructure & Stock of international patents \\
& Population \\
& Aggregate employed S\&T personnel \\
Aggregate R\&D expenditures \\
& Openness to international trade and investment \\
& Strength of protection for IP \\
& $\begin{array}{l}\text { Share of DGP spent on higher education } \\
\text { Stringency of antitrust policies }\end{array}$ \\
\hline B: Cluster-specific innovation \\
environment & $\begin{array}{l}\text { Percentage of R\&D funded by private industry } \\
\text { E-G concentration index (specialization) }\end{array}$ \\
\hline C: Quality of linkages & $\begin{array}{l}\text { Percentage of R\&D performed by universities } \\
\text { Strength of venture capital markets }\end{array}$ \\
\hline
\end{tabular}

Furman, Porter and Stern (2002)

A: Common innovation infrastructure consists of the fundamental elements such as cumulative technological sophistication, human capital and financial resources available for R\&D activity and also resources commitments and policy choices (investment in education and training, intellectual property protection, openness to international trade, $\mathrm{R} \& \mathrm{D}$ tax policies).

B: The cluster-specific innovation environment includes microeconomic environment which supports generating innovations and their commercialization. 
In the other words, the national innovative capacity depends on the microeconomic environment situated in the industrial clusters.

C: The quality of linkages between the common innovation infrastructure and industrial clusters is crucial. For example, the strength of the common innovation infrastructure leads to increase in the innovative output for a cluster innovation environment and vice versa.

The coexistence of the three groups A-C of determinants is defined the national innovative capacity a country's potential to produce a stream innovative products and services (usually measured by number of patents), what can be presented as follows (Figure 1):

\begin{tabular}{|l|l|l|}
\multicolumn{1}{|c|}{$\begin{array}{c}\text { Common innovation } \\
\text { infrastructure }\end{array}$} & $\begin{array}{l}\text { Cluster-specific } \\
\text { commitment for } \\
\text { innovation }\end{array}$ \\
$\begin{array}{ll}\text { Cumulative technological } \\
\text { sophistication }\end{array}$ \\
\hline $\begin{array}{l}\text { Human capital and financial } \\
\text { resources available for R\&D } \\
\text { activities }\end{array}$
\end{tabular}

Figure 1 - National innovative capacity framework according to Furman, Porter and Stern (2002)

The differences in the efficiency of innovation systems, i.e. generating the best possible output from the current level of input, are huge among the EU countries. Although the increasing investment leads theoretically to a higher level of excellence in science and technology, the innovative output grows still slowly in some countries, including the Visegrad group (Poland, Czech Republic, Hungary and Slovakia).

In the article, the Visegrad countries are to be compared according to National innovative capacity framework based on the composite index methodology. As there are surely substantive differences in innovation capacity or performance at the level of regions, the NUTS II regions of the Visegrad countries are evaluated in terms of their innovation performance. Of course, the differences exist thank to agglomeration and location effects and there is an interesting question, what is the efficiency of the regional innovation systems measured by the Cobb- 
Douglas-type function. Also, the factor of a country might be important, and the third evaluation continues in comparing the regions according to their efficiency with respect to countries they belong.

\section{PERFORMANCE OF THE RESEARCH AND INNOVATION SYSTEMS: VISEGRAD COUNTRIES}

The next analysis brings the comparison of the four Visegrad countries in terms of efficiency of their research and innovation systems, also compared to EU average. Data used for the comparison comes from several sources and the composite indices are defined to mirror R\&D intensity, excellence in research, the economic impact of innovation and knowledge-intensity of the economy.

The R\&D intensity is defined as a Gross Domestic Expenditure on R\&D (GERD) as \% of the Gross Domestic Product (GDP). The Frascati Manual expresses Gross Domestic Expenditure on R\&D through four sources of funding (Business Enterprise, Government, Other national sources or Foreign) and four sectors of performance:

- Business Enterprise Expenditure on R\&D (BERD),

- Government Intramural Expenditure on R\&D (GOVERD),

- Higher Education Expenditure on R\&D (HERD),

- Private non-Profit expenditure on R\&D (PNPRD).

The level of R\&D intensity is measured then as the average of the four given indicators, and also its rate is measured as the growth over the last decade.

The excellence in research (science and technology) is defined as the composite index measuring the modernisation of research institutions, the vitality of the research environment and the quality of research outputs (basic and applied research). It consists of four variables:

- Share of highly cited publications in all publications where at least one of the authors has an affiliation in a given country,

- Number of top research universities and public research organizations in a country per million population,

- Number of patent applications per million inhabitants,

- The total value of the European Research grants received divided by the public R\&D performed by the higher education and government sectors.

Index of economic impact of innovation consists of several Innovation Union Scoreboard indicators:

- PCT (Patent Cooperation Treaty) patents applications per billion GDP, 
- Employment in the knowledge-intensive industries as \% of total employment,

- Contribution of medium and high-tech (HT\&MT) product exports to trade balance (calculated as the difference between existing industry trade balance as export minus imports and the theoretical trade balance),

- Sales of new to the market and new to firm innovations as \% of turnover and knowledge-intensive services exports as \% total service exports.

The Knowledge-intensity of the economy is also defined as the composite index mirroring the structural change of economy through the production and employment, business research and development, high-tech exports, technological specialisation and foreign direct investments. It can be divided into five groups (dimensions):

- Size of business R\&D (as the \% of GDP) and the size of the R\&D services sector in the economy (based on total value added),

- Share of persons employed in the knowledge-intensive activities,

- The relative share of knowledge-intensive activities,

- Share of knowledge economy through technological and export specialization - patents and technological advantage, respectively,

- Inward and outward foreign direct investments.

Indicators are defined according to the Research and Innovation performance in EU Member States and Associated countries 2013 (Council for European Studies, 2013).

The following sources are used:

- R\&D Intensity - databases of Eurostat and OECD,

- Excellence in research - (JRC EC, 2012),

- Index of economic impact of innovation (Innovation Union Scoreboard, 2013),

- Contribution of high-tech and medium-tech manufacturing to trade balance - (Annoni and Kozovska, 2010; Innovation Union Scoreboard, 2013);

- Knowledge-intensity of the economy - (JRC EC, 2012).

The highest R\&D intensity among the Visegrad countries exist in the Czech Republic, followed by Hungary and increase in the R\&D investment (R\&D intensity) should theoretically lead to increase in the S\&T excellence. Indeed, the performance of Czech Republic and Hungary is higher in all the research and innovation indices in comparison to Poland and Slovakia (Table 2). 
Table $2-R \& D$ performance in V4 countries

\begin{tabular}{|c|c|c|c|c|c|c|c|c|c|}
\hline \multirow[b]{2}{*}{ Country } & \multicolumn{2}{|c|}{ R\&D intensity } & \multicolumn{2}{|c|}{$\begin{array}{l}\text { Excellence in } \\
\text { S\&T }\end{array}$} & \multirow[t]{2}{*}{\begin{tabular}{|l|} 
Index of \\
economic \\
impact of \\
innovation
\end{tabular}} & \multicolumn{2}{|c|}{$\begin{array}{l}\text { Knowledge- } \\
\text { intensity of } \\
\text { economy } 2010\end{array}$} & \multicolumn{2}{|c|}{$\begin{array}{l}\text { HT\&MT } \\
\text { contribution to } \\
\text { trade balance } \\
2011\end{array}$} \\
\hline & value & \begin{tabular}{|l|} 
growth \\
rate \\
$2010-$ \\
2011 \\
\end{tabular} & value & \begin{tabular}{|l|} 
growth \\
rate \\
$2005-$ \\
2010 \\
\end{tabular} & & value & \begin{tabular}{|l|} 
growth \\
rate \\
$2000-$ \\
2010 \\
\end{tabular} & value & $\begin{array}{l}\text { growth } \\
\text { rate } \\
2000- \\
2011 \\
\end{array}$ \\
\hline $\begin{array}{l}\text { European } \\
\text { Union }\end{array}$ & 2.03 & 0.8 & 47.86 & +3.09 & 0.612 & 48.75 & +0.93 & 4.2 & +4.99 \\
\hline $\begin{array}{l}\text { Czech } \\
\text { Republic }\end{array}$ & 1.84 & +4.23 & 29.9 & +4.58 & 0.497 & 39.58 & +2.91 & 3.82 & +42.62 \\
\hline Huı & 1.21 & +4.64 & 31.88 & +2.03 & 0.527 & 50.23 & +1.87 & 5.84 & +9.04 \\
\hline Poland & 0.77 & +1.6 & 20.47 & +4.45 & 0.313 & 31.78 & +1.65 & 0.88 & +37.56 \\
\hline $\begin{array}{l}\text { Slovak } \\
\text { Republic }\end{array}$ & 0.68 & +0.41 & 17.73 & +3.85 & 0.479 & 31.64 & +0.07 & 4.35 & +32.26 \\
\hline
\end{tabular}

Research and Innovation Performance in the EU Member States and Associated Countries 2013 (Council for European Studies, 2013).

\section{INNOVATION PERFORMANCE OF THE VISEGRAD REGIONS}

The innovation policy is a part of a public policy aiming to improve social welfare. The innovation system plays a crucial role in the political discussions and brings a new range of innovative tools focused on the networking, clustering and personal mobility simultaneously. The innovation policy is one of the horizontal policies and it works as a connection between economy, industry and research.

Countries seek to increase investment into new structures and tools for the innovation policy, which should improve their competitiveness. The World Economic Forum gives a generally accepted definition of the macroeconomic competitiveness: competitiveness is the "set of institutions, policies and factors that determine the level of productivity of a country" (Schwab and Porter, 2007).

The EU indicates regional disparities and although almost all the new member countries achieved interesting growth in the sense of the index of competitiveness, still, many regions in the new member countries are evaluated as considerably less competitive than the European average. The Regional Competitiveness Index RCI (Annoni and Kozovska, 2010), is evaluating three pillars with the scales according to the region stage (medium, intermediate, high): 
Table 3 - RCI of the Visegrad regions

\begin{tabular}{|c|c|c|}
\hline First pillar (sub-index 1) & Second pillar (Sub-index 2) & Third pillar (Sub-index 3) \\
\hline $\begin{array}{ll}\text { - } & \text { Institutions } \\
\text { - } & \text { Macroeconomic } \\
& \text { stability } \\
\text { - } & \text { Infrastructure } \\
\text { - } & \text { Health } \\
\text { - } & \text { Quality of primary } \\
& \text { and secondary } \\
& \text { education }\end{array}$ & $\begin{array}{l}\text { - Higher education and } \\
\text { training } \\
\text { - } \quad \text { Labour market } \\
\text { efficiency } \\
\text { - } \quad \text { Market Size }\end{array}$ & $\begin{array}{ll}\text { - } & \text { Technological } \\
\text { Readiness } \\
\text { - } & \text { Business } \\
\text { - Sophistication } \\
\text { - Innovation }\end{array}$ \\
\hline
\end{tabular}

EU Regional Competitiveness Index (Annoni and Kozovska, 2010)

The Pillar 1 includes factors necessary for the basic functioning of any economy. The Pillar 2 describes a more sophisticated economy, having a higher potential skilled labour force and a structured labour market. Finally, the Pillar 3 is mirroring high-tech and innovation factors and competitiveness of an economy.

The position of the Visegrad countries is shown in the following table aiming at the most important variables/factors of innovation: GDP\%, development stage and value of the three pillars - sub-indexes for all Visegrad regions, the value of $\mathrm{RCI}$, and ranking of regions among all EU regions. The overall RCI index constructed by the DG Regional Policy is using weights of the sub-indices differently according to region's development stage as follows: Medium stage: $0.4,0.5,0.1$; intermediate stage: $0.3,0.5,0.2$; high stage: $0.2,0.5,0.3$.

Figure 2 shows widespread interregional but also international differences existing in the Visegrad group (subindices). The west-east divide is partially visible in all the countries. Hungarian regions are mostly competitive in the pillar of the basic economy functioning (the darker parts in Figure 2), but RCI is highlighting only the capital city region as competitive. The Czech Republic has the highest proportion of the most competitive regions in the Visegrad group (overall RCI). Slovak regions show the same picture in all indices - decreasing values from the west to the east of the country. This contrast is visible on the Figure 2, primarily in the second and third sub-index. Poland is much more varied, although the better performing regions are the central Mazovia region and the southern belt of the regions Lower Silesia, Opolskie, Silesia and Lesser Poland.

RCI of the Visegrad regions as well as values of the three pillars - subindices) are given in Table 4 (SI1 - sub-index Basic, SI2- sub-index Efficiency, SI3 - subindex Innovation). 

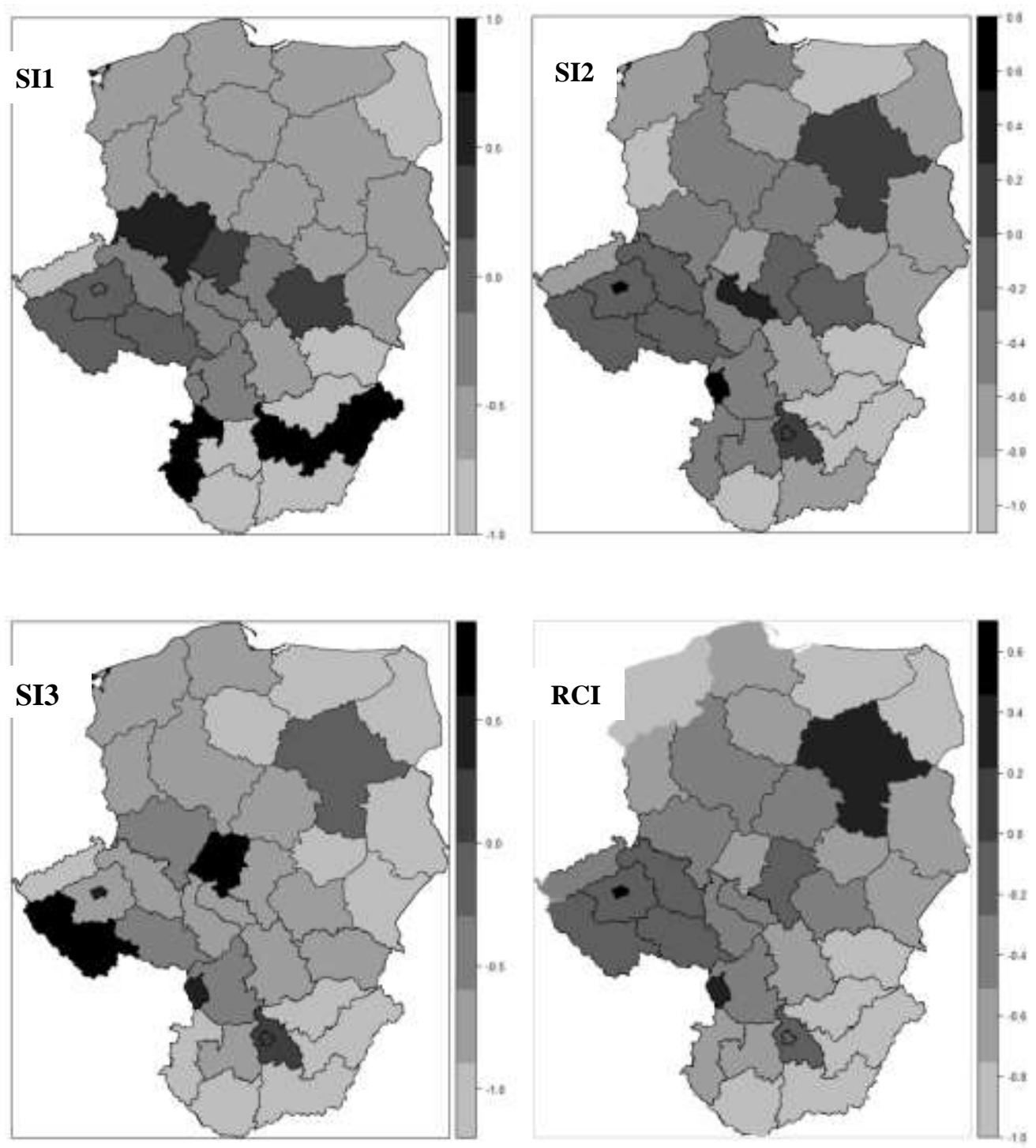

Figure 2 - Components of the regional competitive indices - the NUTS2 level (The higher level of index, the darker region is.)

\section{METHODOLOGY: THE RELATIVE INNOVATION EFFICIENCY OF THE VISEGRAD REGIONS}

If considering only ratio as a sign of the efficiency of business R\&D in producing patents, Switzerland, Germany and the Netherlands are the European leaders (JRC EC, 2014). On the contrary, Central and Eastern European countries invent the fewest number of EPO patents per euro of business R\&D expenditure. The concept of the knowledge production function (Liu and Buck, 2007) may serve for the measurement of the effectiveness as a more advanced approach than in the EC report. The function has a form of the Cobb-Douglas-type function and can be used (Fritsch and Slavtchev, 2011) for analysing the technical efficiency of the innovation process explaining the relationship between innovative input and output. 
Table 4-RCI of the Visegrad regions (sub-indices)

\begin{tabular}{|c|c|c|c|c|c|c|c|c|}
\hline Country & $\begin{array}{l}\text { Region } \\
\text { ID }\end{array}$ & STAGE & GDP \% & SI1 & SI2 & SI3 & RCI & Rank \\
\hline \multirow{8}{*}{$\begin{array}{l}\text { Czech } \\
\text { Republic }\end{array}$} & CZ01 & HIGH & 171.8 & 0.118 & 0.767 & 0.533 & 0.567 & 36 \\
\hline & $\mathrm{CZ02}$ & INTERMEDIATE & 75.2 & -0.096 & -0.16 & -0.648 & -0.238 & 169 \\
\hline & CZ03 & MEDIUM & 71.1 & -0.098 & -0.21 & 0.677 & -0.212 & 164 \\
\hline & $\mathrm{CZ04}$ & MEDIUM & 61.7 & -0.912 & -0.64 & -0.94 & -0.491 & 193 \\
\hline & $\mathrm{CZ} 05$ & MEDIUM & 65.9 & -0.144 & -0.27 & -0.687 & -0.261 & 171 \\
\hline & CZ06 & MEDIUM & 71.7 & -0.092 & -0.26 & -0.542 & -0.221 & 166 \\
\hline & $\mathrm{CZ} 07$ & MEDIUM & 62.3 & -0.288 & -0.41 & -0.857 & -0.406 & 183 \\
\hline & CZ08 & MEDIUM & 67.5 & -0.38 & 0.523 & -0.89 & -0.503 & 197 \\
\hline \multirow[t]{7}{*}{ Hungary } & HU10 & HIGH & 102.9 & 0.748 & 0.177 & 0.015 & -0.057 & 144 \\
\hline & HU21 & MEDIUM & 58.2 & -0.814 & -0.44 & -0.825 & -0.628 & 207 \\
\hline & HU22 & MEDIUM & 61.5 & 0.79 & -0.503 & -0.902 & -0.658 & 210 \\
\hline & HU23 & MEDIUM & 42.7 & -0.988 & -0.87 & -0.932 & -0.923 & 236 \\
\hline & HU31 & MEDIUM & 40.1 & -0.942 & -0.83 & -1.13 & -0.905 & 232 \\
\hline & HU32 & MEDIUM & 39.4 & 0.99 & -0.867 & -1.073 & -0.937 & 237 \\
\hline & HU33 & MEDIUM & 41.8 & -0.944 & -0.783 & -1.048 & -0.874 & 231 \\
\hline \multirow[t]{16}{*}{ Poland } & PL11 & MEDIUM & 50 & -0.488 & -0.453 & -0.73 & -0.495 & 195 \\
\hline & PL12 & INTERMEDIATE & 87.1 & -0.532 & 0.207 & -0.07 & -0.07 & 147 \\
\hline & PL21 & MEDIUM & 46.7 & 0.356 & -0.24 & -0.627 & -0.325 & 176 \\
\hline & PL22 & MEDIUM & 57.8 & -0.346 & -0.047 & -0.683 & -0.23 & 168 \\
\hline & PL31 & MEDIUM & 36.9 & -0.698 & -0.603 & -0.982 & -0.679 & 214 \\
\hline & PL32 & MEDIUM & 36.7 & -0.598 & -0.637 & -0.942 & -0.652 & 208 \\
\hline & PL33 & MEDIUM & 41.9 & -0.608 & -0.643 & -1.188 & -0.684 & 215 \\
\hline & PL34 & MEDIUM & 40.4 & -0.816 & -0.787 & -1.035 & -0.823 & 227 \\
\hline & PL41 & MEDIUM & 56.9 & -0.492 & -0.487 & -0.712 & -0.511 & 198 \\
\hline & PL42 & MEDIUM & 48.9 & -0.472 & -0.79 & -0.702 & 0.654 & 209 \\
\hline & PL43 & MEDIUM & 48.2 & -0.542 & -0.843 & -0.798 & -0.718 & 218 \\
\hline & PL51 & MEDIUM & 59.2 & 0.438 & -0.427 & -0.595 & -0.448 & 187 \\
\hline & PL52 & MEDIUM & 45.2 & 0.376 & -0.663 & 0.858 & -0.568 & 204 \\
\hline & PL61 & MEDIUM & 47.3 & -0.612 & -0.78 & -0.912 & -0.726 & 219 \\
\hline & PL62 & MEDIUM & 40.5 & -0.648 & -1.027 & -0.938 & -0.866 & 230 \\
\hline & PL63 & MEDIUM & 53.6 & -0.538 & -0.527 & -0.645 & -0.543 & 201 \\
\hline \multirow[t]{4}{*}{ Slovakia } & SK01 & HIGH & 160.3 & -0.186 & 0.56 & 0.41 & 0.366 & 63 \\
\hline & SK02 & MEDIUM & 66.1 & -0.354 & -0.33 & -0.545 & -0.361 & 179 \\
\hline & SK03 & MEDIUM & 53.3 & -0.54 & -0.81 & -0.792 & -0.7 & 217 \\
\hline & SK04 & MEDIUM & 46 & -0.85 & -1.047 & -0.735 & -0.829 & 228 \\
\hline
\end{tabular}

EU Regional Competitiveness Index (Annoni and Kozovska, 2010)

Cobb-Douglas-type function can be expressed according to Griliches (1979, cited in Fritsch and Slavtchev, 2011, p. 906) and Jaffe (1989, cited in Fritsch and Slavtchev, 2011, p. 906) as $Y_{i}=A_{i} X_{i}^{\beta_{i}}$, explaining the relation between innovative output $Y$ of unit $i$ and the set of inputs $X$ of unit $i$, where $A_{i}$ is an inefficiency parameter of unit $i$. Although the number of patents, as the indicator of innovative output, has some disadvantages for the research (not all inventions are patented, patents are just a part of innovation activity), they are still widely used and easily applicable to study outcomes of the innovative efforts. A deterministic approach (negative binomial regression - Poisson distribution of patents) can exploit the business $R \& D$ expenditures at the input side and together 
with the dummy variable for each country, to evaluate the innovative effectiveness of Visegrad regions. Certainly, for the knowledge production function is appropriate to assume time lag of four years between using innovative input (business R\&D expenditures - firms are considered as the main patent producers) and generating the innovative output (patents).

Table 5 - Innovation Efficiency of the Visegrad regions

\begin{tabular}{|c|c|c|c|c|}
\hline ID & Name & Efficiency & $\begin{array}{l}\text { Number of } \\
\text { patents }(2006)\end{array}$ & $\begin{array}{l}\text { BERD } \\
\text { mil. } €(2010)\end{array}$ \\
\hline CZ01 & Prague & 0.0482 & 22.80 & 615.22 \\
\hline $\mathrm{CZ02}$ & Central Bohemian Region & 0.0422 & 14.56 & 517.64 \\
\hline CZ03 & Southwest & 0.0752 & 6.65 & 126.56 \\
\hline CZ04 & Northwest & 0.1844 & 10.21 & 39.05 \\
\hline CZ05 & Northeast & 0.2423 & 23.92 & 252.09 \\
\hline CZ06 & Southeast & 0.5089 & 31.08 & 198.04 \\
\hline CZ07 & Central Moravia & 0.5011 & 27.94 & 166.15 \\
\hline CZ08 & Moravia-Silesia & 0.0403 & 7.62 & 341.25 \\
\hline HU10 & Central Hungary & 0.2420 & 78.19 & 660.31 \\
\hline HU21 & Central Transdanubia & 0.1238 & 6.77 & 38.04 \\
\hline HU22 & Western Transdanubia & 0.4265 & 15.21 & 29.57 \\
\hline HU23 & Southern Transdanubia & 0.0710 & 3.73 & 9.01 \\
\hline HU31 & Northern Hungary & 0.0941 & 5.13 & 24.17 \\
\hline HU32 & Northern Great Plain & 0.1188 & 7.06 & 60.96 \\
\hline HU33 & Southern Great Plain & 0.1361 & 7.37 & 41.07 \\
\hline PL11 & Lodzkie & 1.0000 & 34.08 & 32.63 \\
\hline PL12 & Mazovia & 0.2399 & 48.64 & 394.4 \\
\hline PL21 & Lesser Poland & 0.8993 & 40.18 & 103.52 \\
\hline PL22 & Silesia & 0.2969 & 23.35 & 120.15 \\
\hline PL31 & Lublin Province & 0.0779 & 6.42 & 22.32 \\
\hline PL32 & Podkarpacia & 0.0604 & 5.52 & 47.72 \\
\hline PL33 & Swietokrzyskie & 0.0715 & 5.63 & 7.12 \\
\hline PL34 & Podlasie & 0.0357 & 2.65 & 8.42 \\
\hline PL41 & Greater Poland & 0.2871 & 18.92 & 59.2 \\
\hline PL42 & West Pomerania & 0.0569 & 4.45 & 3.97 \\
\hline PL43 & Lubusz & 0.1433 & 10.00 & 5.61 \\
\hline PL51 & Lower Silesia & 0.3367 & 19.83 & 43.39 \\
\hline PL52 & Opolskie region & 0.0263 & 1.71 & 7.45 \\
\hline PL61 & Kuyavian-Pomerania & 0.0458 & 4.25 & 54.59 \\
\hline PL62 & Warmian-Masuria & 0.0106 & 0.20 & 1.68 \\
\hline PL63 & Pomerania & 0.0773 & 7.42 & 67.35 \\
\hline SK01 & Bratislava Region & 0.2400 & 8.05 & 58.74 \\
\hline SK02 & West Slovakia & 0.1761 & 7.18 & 92.36 \\
\hline SK03 & Central Slovakia & 0.0607 & 2.14 & 25.7 \\
\hline SK04 & East Slovakia & 0.1863 & 5.98 & 21.02 \\
\hline \multicolumn{2}{|l|}{ StDev } & 0.2280 & 16.11 & 174.77 \\
\hline \multirow{2}{*}{\multicolumn{2}{|c|}{$\begin{array}{l}\text { Var } \\
\text { Max }\end{array}$}} & 0.0520 & 259.51 & 30545.69 \\
\hline & & 1.0000 & 78.19 & 660.31 \\
\hline \multirow{2}{*}{\multicolumn{2}{|c|}{ Min }} & 0.0106 & 0.20 & 1.68 \\
\hline Median & & 0.1238 & 7.42 & 47.72 \\
\hline
\end{tabular}

Patents and R\&D expenditures: OECD - innovative indicators. EUROSTAT science. technology and innovation 
The extensive regional differences in efficiency of the regional innovation systems can be found largely in Poland covering both the highest (Lodzkie. Lesser Poland) and lowest (Warmian-Masuria) regional innovation efficiency in the whole territory of interest. It is worth to note the meaning of the relative efficiency - it shows only the relation between the input (BERD) and output (patents). The most performing regions in innovation (capital regions) do not belong to most efficient regions in number of patents according to expenditures on R\&D The relative innovation efficiency of the Visegrad regions is shown in Figure 3:

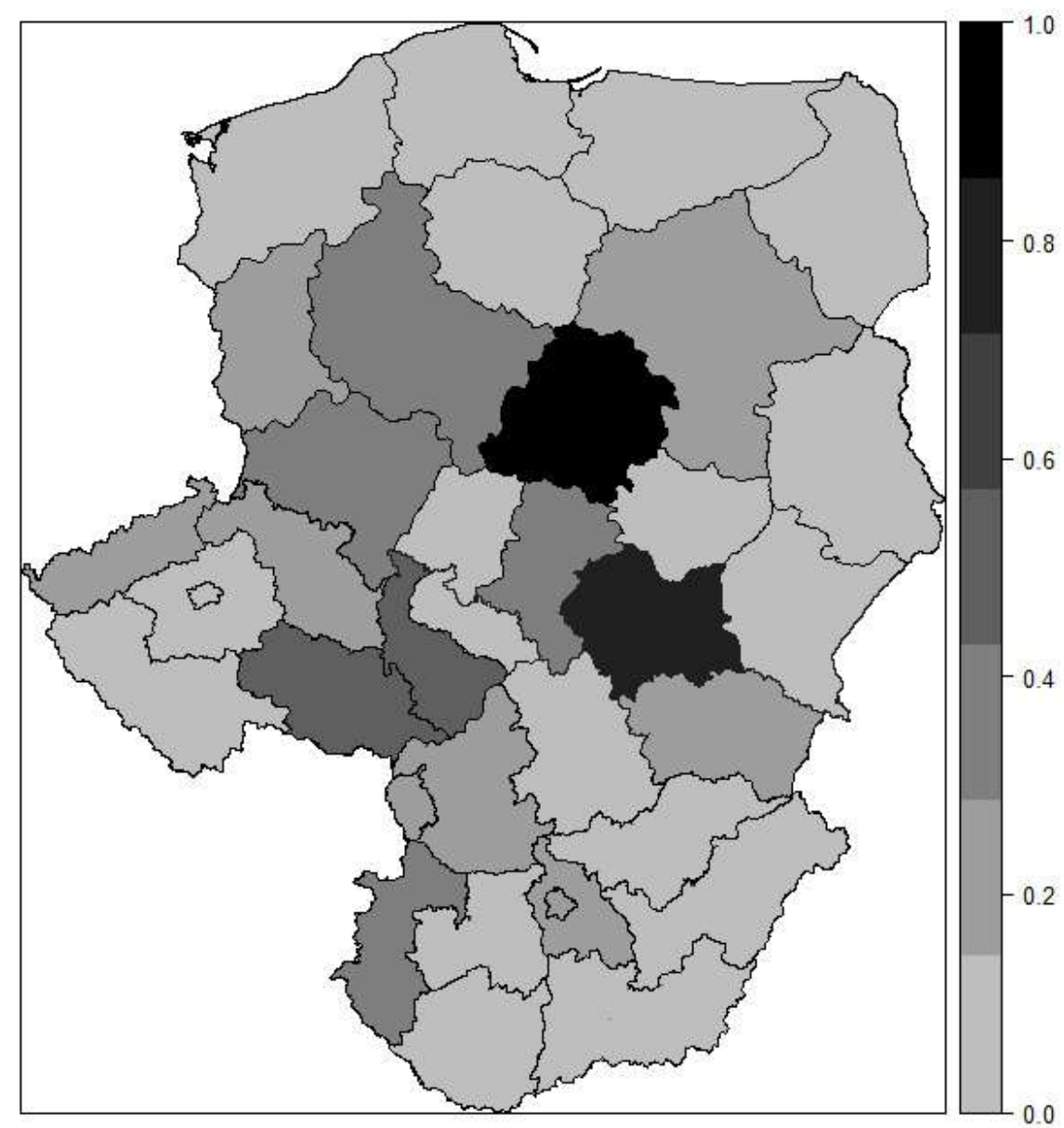

Figure 3 - Innovation efficiency of the Visegrad regions (the higher level of index. the darker region is)

\section{POLITICAL ASPECTS OF INNOVATIONS AND IMPACT OF REGULATION ON INNOVATIONS}

Regulations (rules of public authorities and governmental bodies) are aimed to maximize collective welfare or to reach distributive goals. Innovation can be regulated in three ways: 
- Economic regulation on innovation (competition policies. price regulation. market entry regulations. regulation of natural monopolies and public utilities).

- Social regulation on innovation (impact of environmental regulation. safety regulations mainly in the health sector).

- Institutional regulation on innovation (administrative regulations - impact of liability rules on innovation).

The Cobb-Douglas type of production function can serve as the description of the entity (region. country) ability to transform innovative input to innovative output. Although. knowledge production function does not treat the whole innovation process. the production of knowledge can be considered as the precondition for innovation (the invention transforms into innovation in the process of commercialization - in the process of bringing invention to the market). The knowledge production function can be used as the starting point for evaluating closeness of a region to efficiency frontier.

The closeness to efficiency frontier is supposed to be influenced by the national conditions (environment), in which the transformation process is running. The environment consists of regulation (economic, social, and institutional) and several other factors. We also assume the regional GDP as one of the factors contributing to regional innovation performance. The Figure 4 shows the spatial distribution of the innovation efficiency with the country as dummy variable on the left side (specific conditions in each country, regulation and other factors), the innovation efficiency without dummy variable national factor on the right side and finally, distribution of regional GDP per capita.

The Figure 4 demonstrates similar picture of the regional innovation efficiency either with or without the country factor. The value of correlation coefficient 0.96 is high. The efficiency without country dummy factor is lower for all regions but the Polish region Lodzkie - the benchmark in the group with efficiency equal to 1.0. Differences in the efficiency level are primarily visible in Slovakia. In this case, the patent regulation plays a role. The next table shows the differences between achieved innovative efficiency in more details.

The values of efficiency calculated for both with and without dummy variable are shown in the Table 6. 


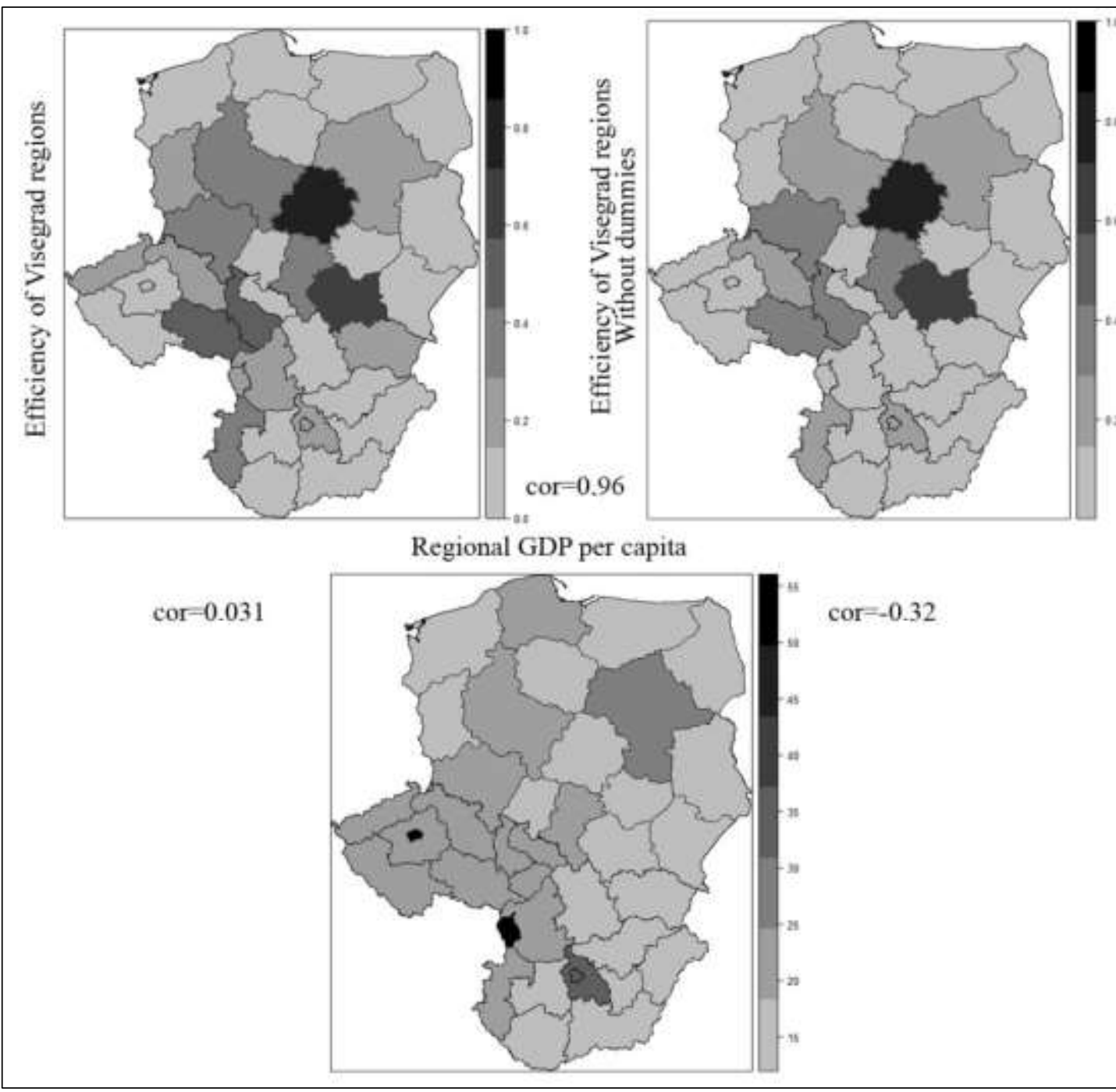

Figure 4-The factors of environment and innovation efficiency of the Visegrad regions 
Table 6 - The comparison of Visegrad regions efficiency

\begin{tabular}{|c|c|c|c|c|c|}
\hline ID & Name & $\begin{array}{l}\text { Efficiency with } \\
\text { dummies }\end{array}$ & Ranking & $\begin{array}{l}\text { Efficiency } \\
\text { without } \\
\text { dummies }\end{array}$ & Ranking \\
\hline CZ01 & Prague & 0.0482 & 29 & 0.0385 & 29 \\
\hline $\mathrm{CZO2}$ & Central Bohemian Region & 0.0422 & 31 & 0.0335 & 31 \\
\hline CZ03 & Southwest & 0.0752 & 23 & 0.0544 & 26 \\
\hline $\mathrm{CZ04}$ & Northwest & 0.1844 & 14 & 0.1245 & 13 \\
\hline CZ05 & Northeast & 0.2423 & 9 & 0.1657 & 10 \\
\hline CZ06 & Southeast & 0.5089 & 3 & 0.3278 & 4 \\
\hline CZ07 & Central Moravia & 0.5011 & 4 & 0.3213 & 5 \\
\hline CZ08 & Moravia-Silesia & 0.0403 & 32 & 0.0312 & 32 \\
\hline HU10 & Central Hungary & 0.242 & 10 & 0.1515 & 11 \\
\hline HU21 & Central Transdanubia & 0.1238 & 18 & 0.0756 & 16 \\
\hline HU22 & Western Transdanubia & 0.4265 & 5 & 0.2302 & 9 \\
\hline HU23 & Southern Transdanubia & 0.071 & 25 & 0.0455 & 27 \\
\hline HU31 & Northern Hungary & 0.0941 & 20 & 0.0589 & 23 \\
\hline HU32 & Northern Great Plain & 0.1188 & 19 & 0.0730 & 19 \\
\hline HU33 & Southern Great Plain & 0.1361 & 17 & 0.0824 & 15 \\
\hline PL11 & Lodzkie & 1 & 1 & 1.0000 & 1 \\
\hline PL12 & Mazovia & 0.2399 & 12 & 0.2573 & 8 \\
\hline PL21 & Lesser Poland & 0.8993 & 2 & 0.9179 & 2 \\
\hline PL22 & Silesia & 0.2969 & 7 & 0.2987 & 6 \\
\hline PL31 & Lublin Province & 0.0779 & 21 & 0.0753 & 18 \\
\hline PL32 & Podkarpacia & 0.0604 & 27 & 0.0586 & 24 \\
\hline PL33 & Swietokrzyskie & 0.0715 & 24 & 0.0688 & 21 \\
\hline PL34 & Podlasie & 0.0357 & 33 & 0.0341 & 30 \\
\hline PL41 & Greater Poland & 0.2871 & 8 & 0.2840 & 7 \\
\hline PL42 & West Pomerania & 0.0569 & 28 & 0.0546 & 25 \\
\hline PL43 & Lubusz & 0.1433 & 16 & 0.1388 & 12 \\
\hline PL51 & Lower Silesia & 0.3367 & 6 & 0.3324 & 3 \\
\hline PL52 & Opole region & 0.0263 & 34 & 0.0251 & 34 \\
\hline PL61 & Kuyavian-Pomerania & 0.0458 & 30 & 0.0444 & 28 \\
\hline PL62 & Warmian-Masuria & 0.0106 & 35 & 0.0098 & 35 \\
\hline PL63 & Pomerania & 0.0773 & 22 & 0.0755 & 17 \\
\hline SK01 & Bratislava Region & 0.24 & 11 & 0.0856 & 14 \\
\hline SK02 & West Slovakia & 0.1761 & 15 & 0.0665 & 22 \\
\hline SK03 & Central Slovakia & 0.0607 & 26 & 0.0277 & 33 \\
\hline SK04 & East Slovakia & 0.1863 & 23 & 0.0700 & 20 \\
\hline \multicolumn{2}{|l|}{ StDev } & 0.2280 & & 0.2217 & \\
\hline \multicolumn{2}{|l|}{ Var } & 0.0520 & & 0.0491 & \\
\hline \multicolumn{2}{|l|}{ Max } & 1.0000 & & 1.0000 & \\
\hline \multicolumn{2}{|l|}{ Min } & 0.0106 & & 0.0098 & \\
\hline \multicolumn{2}{|c|}{ Median } & 0.1238 & & $\mathbf{0 . 0 7 5 3}$ & \\
\hline
\end{tabular}




\section{CONCLUSION}

Visegrad countries are among the worst performers in innovation and competitiveness in the European Union. The highest R\&D intensity among the Visegrad countries exist in the Czech Republic, followed by Hungary, and the innovation performance is led by the capital regions of Prague and Budapest. EU Regional Competitiveness Index derived from the World Economic Forum which constructed the Global Competitiveness Index can serve for reasoning on the whole Visegrad territory of NUTS II regions to see their performance. The approach combines the views of the regions as 'basic', 'efficiency', and "innovation" driven regional economies covered by three pillars of variables.

The Czech Republic has the highest proportion of the most competitive regions in the Visegrad group (overall RCI). Slovak regions show the same picture in all indices - decreasing values from the west to the east of the country.

The concept of the knowledge production function of the Cobb-Douglas type may serve for the measurement of the efficiency as a more advanced approach than in the EC report explaining the relationship between innovative input and output. The results are certainly different if replacing performance by the efficiency. Instead of the capital regions, several Polish regions (Lodzkie. Lesser Poland) and Czech regions (Central Moravia and South-East Moravia) belong to most efficient regions in innovation.

The factor of a country is not much important - so the Visegrad group of countries is fairly homogeneous in the regulatory framework related to research, development and innovation.

\section{ACKNOWLEDGEMENT}

This work was supported by the project of Ministry of Education of the Slovak Republic: VEGA-1/0454/15 Redefining regional development moving towards resilient regions.

\section{REFERENCES}

Annoni, P. and Kozovska, K., 2010. EU Regional Competitiveness Index 2010. Luxembourg: Publications Office of the European Union. Available at: http://publications.jrc.ec.europa.eu/repository/bitstream/111111111/13666/1/rci_ eur_report.pdf [Accessed 17 June 2015].

Council for European Studies, 2013. Research and Innovation performance in the EU Member States and Associated Countries. Innovation Union Progress at Country Level. Report of European Commission. Available at: https://ec.europa.eu/research/innovation-union/pdf/state-of-the-

union/2012/innovation_union_progress_at_country_level_2013.pdf [Accessed 17 June 2015]. 
Freeman, Ch., 1995. The "National System of Innovation" in historical perspective. Journal of Economics, 19, pp. 5-24.

Fritsch, M. and Slavtchev, V., 2011. Determinants of the Efficiency of Regional Innovation Systems. Regional Studies, 45(7), pp. 905-918.

Furman, J.L., Porter M.E. and Stern S., 2002. The determinants of national innovative capacity. Research Policy, 31, pp. 899-933.

Innovation Union Scoreboard, 2013. Report of European Commission. Available at: http://era.gv.at/object/document/365/attach/ius-2013_en.pdf [Accessed 17 June 2015]. DOI: 10.2769/72530.

JRC EC, 2012. Joint Research Centre of the European Commission. Composite indicators measuring structural change, monitoring the progress towards a more knowledge-intensive economy in Europe. Luxembourg: Publications Office of the European Union, 56 pp.

JRC EC, 2014. Joint Research Centre of the European Commission. The 2014 EU Industrial R\&D Investment Scoreboard. Available at: http://iri.jrc.ec.europa.eu/documents/10180/354280/EU\%20R\%26D\%20Scorebo

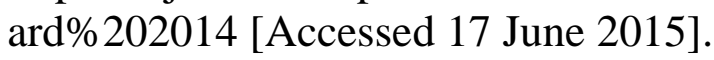

Lundvall, B.A. and Johnson, B., 1994. The learning economy. Journal of Industry Studies, 1. pp. 23-42.

Liu, X. and Buck, T.W., 2007. Innovative Performance and Channels for International Technology Spillovers: Evidence from Chinese High-Tech Industries, Research Policy, 36(3), pp.355-366. DOI: 10.1016/j.respol.2006.12.003.

Porter, M.E., 1990. The Competitive Advantage of Nations. New York: Free Press, MacMillan. pp. 17-48.

Schiuma. G. and Lerro. A., 2008. Knowledge-based capital in building reional innovation capacity. Journal of Knowledge Management, 12 (5), pp. 121-136. DOI: $10.1108 / 13673270810902984$.

Schwab. K. and Porter, M. E., 2007. The Global Competitiveness Report 20072008. World Economic Forum, Geneva, Switzerland. 


\section{ABOUT AUTHORS}

Prof. RNDr. Oto Hudec, CSc., Professor at the Department of Regional Science and Management. Faculty of Economics, Technical University of Kosice. e-mail: oto.hudec@ @ tuke.sk, http://orcid.org/0000-0002-8877-8647.

Ing. Martina Prochádzková, PhD., Doctoral student at the Department of Regional Science and Management, Faculty of Economics, Technical University of Kosice. e-mail: martina.prochadzkova@gmail.com. 